\title{
Forage Introduction to Support Development of Cattle in Sangkub District
}

\section{Femi H. Elly ${ }^{1}$, A.H.S. Salendu ${ }^{1}$, Ch. L. Kaunang ${ }^{1}$, Indriana ${ }^{2}$, R. Pomolango ${ }^{3}$, and Syarifuddin ${ }^{4}$}

\author{
${ }^{1}$ Department of Social Economics Faculty of Animal Husbandry, University of Sam Ratulangi, Manado \\ ${ }^{2}$ UniversityofIchsan, Gorontalo \\ ${ }^{3}$ UniversityMuhamadyah, Gorontalo \\ ${ }^{4}$ PEMDA, North Bolaang Mongondow Regency \\ Corresponding Email: femi_elly@yahoo.co.id
}

\begin{abstract}
Farmers in SangkubDistrict develop cattle as a source of income, so the government seeks to give serious attention to its development.The problem is there are constrains in its development, one of them related to feed.This research has been conducted with the aim to know how far the availability of feed for cattle.The research method used is survey method, with the respondents amounted to 15 farmers determined by purposive sampling ie farmers belonging to the group, the development of science and technology for the region.Data analysis used is descriptive analysis.The results showed the ownership of cattle by each farmer ranged from 2-6 tail with a total of 43 tails.The results showed ownership by each farmers ranged from 2-6 cattle to a total of 43 cattle.Cattle have the potential to be developed in terms of available resources. However, the food consumed is the grass that grows wild and corn waste.This is due to high quality forage, not yet available continuously.Knowledge offarmers about quality feed is still low, so the introduction offeed has been done by the team. Based on results of the research can be concluded that the introduction of cattle feed has been done and responded well by farmers. Suggestions submitted, need to socialize about the development of forage with business orientation and environmentally friendly. Keywords-Cattle, introduction, forage.
\end{abstract}

\section{INTRODUCTION}

The government's attention to the agricultural sector is closely linked to the livestock sector. According Ikbal (2015), livestock development in this case is always associated with the reorientation of agricultural development policies. Related to the development of livestock, cattle is one of the commodities that support its development.
Farmers in Sangkub District develop cattle as a source of income, so the government seeks to give serious attention to its development. The problem is there are constraints in the development of cattle farming, one of which is related to feed. Feed problems are a problem faced by farmers in any area such as according to Alfian et al (2012), Gunawan et al (2013), Rahmansyah et al (2013), Rusdiana and Adawiyah, (2013) and Nugraha et al (2013). Based on that thought has been conducted research with the aim to know how far the availability of feed for cattle.

\section{MATERIALS AND METHODS}

The materials used in this study are land, cattle and agricultural waste. Land is land under coconut that is used for the development of cattle. Cattle are amounts owned by farmers. Agricultural waste is residue of corn consumed by cattle. The forages introduced are dwarf grasses. The research method used is survey method. Respondents as many as 15 farmers are determined by purposive sampling ie farmers belonging to the groupdevelopment of science and technology for the region. Data analysis used is descriptive analys is .

\section{RESULTS AND DISCUSSION}

Sangkub district has an area of about 30.58 percent of area of North BolaangMongondow Regency. The agricultural family amounts to $70.93 \%$ and $30.13 \%$ of family, is a farming family, that is, the family whose members are farm laborers. The agricultural sector is prime mover of the region's economy so that its development becomes government's priority. The number of cattle each farmer ranged from 2-6 to head with a total of 43 head.

The results showed that cattle consume corn waste about 8-10 kg and grass about 5-10 kg per head per 
day.AccordingNurdiati et al (2012), development of local cattle is done by utilizing agricultural waste. However, high quality forage is needed to increase productivity of cattle. According to Dianita et al (2014), sustainable forage production is an important factor in cattle production systems. Constraints that are often encountered in cattle farming is low productivity of cattle due to quality of feed that is not in accordance with nutritional needs of livestock (Lamid et al 2014). Based on results of the research, introduction of forage through the planting of dwarf grass under coconut tree (Figure 1).

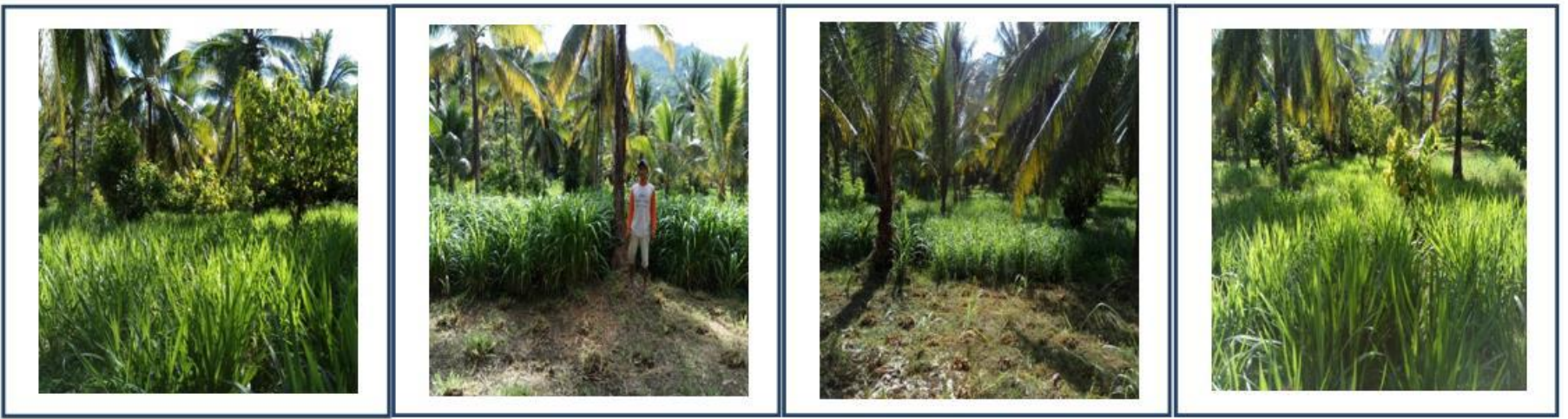

Fig.1. Grasses Developed Under Coconut Trees in Sangkub District

The introduction of forage referred to as integrated cattle development. These developments according to Walia and Kaur (2013), Suroyo et al (2013), Baba et al (2014), and Wahyuni (2015), are known as integration systems of cattle-crop. Munandar et al (2015) stated that the farming system integration is an alternative to climate change mitigation.

\section{CONCLUSIONS AND SUGGESTIONS}

Based on results of the research can be concluded that the introduction of cattle feed has been done and responded well by farmers. Suggestions submitted, need to socialize about the development of forage with business orientation and environmentally friendly.

\section{ACKNOWLEDGEMENT}

Thanks go toKemenristekdikti which has provided an opportunity for the author to obtain funds through the scheme of science and technology for the region (IbW) 2017.

\section{REFERENCES}

[1] Alfian,Y., F.I.Hermansyah., E.Handayanto., Lutojoand W.P.S.Suprayogi, 2012. Analysis ofthe capacity ofruminantsin the dry seasonindryland farmingareasinSeminGunungKidulRegency. Tropical Animal Husbandry, Vol. 1(1). Okt.p:33-42.

[2] Baba. S., S.N. Sirajuddin., A. Abdullah and M. Aminawar. 2014. Barriers to Adoption Integration of
Corn and Cattlein Maros, Gowa and Takalar Regency. JITP, Vol 3 No 2, Jan 2014. p: 114-120.

[3] Dianita, R., A. RahmanSy., H. Syarifuddin., SyafwanandZubaidah. 2014. Improvement of Forage Feed through Introduction of LegumIndigofera and Making Silage Legum-Maize Straw on Farmer's GroupinPalayangan District. Journal of Community Service

29 (3) : 76-79.

[4] Gunawan, E.R., D. Suhendra and D. Hermanto, 2013. Optimizing Integration of Cattle, Corn and Seaweed (Flare) on Animal Feed Processing Technology, Based on Corn Waste Agriculture-Seaweed to Support One Million Earth Cattle Program (BSS)inWest Nusa Tenggara. Livestock Bulletin 37 (3):157-164.

[5] Ikbal, M. 2015. Policy Evaluation of Livestock Control in ParigiDistrict, ParigiMoutongRegency. EJournal Katalogis. Vol.3 No. 10. Oct 2015.p:167-172.

[6] Lamid, M., T. Nurhajatiand R.S. Wahjuni. 2014. Potential of Plus Concentrate for Beef Fattening at HarapanMulya Livestock Group and Livestock Farmer Group Jaya Mulya in BangkalanMadurRegency.Agroveteriner. Vol 3 No, 1 Dec 2014.p:1-7.

[7] Munandar., F. Gustiar. Yakup., R. Hayati and A.I. Munawar. 2015. Crop-Cattle Integrated Farming System : an Alternative of Climatic Change Mitigation. Media Peternakan, Agustus 2015, 38 (2).p:95-103. 
[8] Nugraha,B.D., E. Handayantaand E.T.Rahayu, 2013.Analysis ofthe Capacity of Ruminantsin Rainy Season in Dryland Farming Areasin District of Semin, Gunungkidul Regency. Tropical Animal Husbandry, Vol. 2 (1). Jan. 2013: 34-40.

[9] Nurdiati,K., E. Handayanta and Lutojo. 2012. Cattle Production Efficiency in Dry Season in Ranch Regional People Dryland Agriculture Gunung Kidul. Tropical Animal Husbandry, Vol 1(1), Oct, 2012.p:5258.

[10] Rahmansyah,M., A.Sugiharto., A.Kanti and I.M.Sudiana, 2013.Alertness Feed on aSmall Scale Cattle as aAdaptation Strategy to Climate Change through the Utilization of Local Flora Biodiversity. Bulletin Ranch,Vol 37(2): 95-106.

[11] Rusdiana,S and C.R.Adawiyah, 2013. Economic Analysis and Business Prospects Crops and Cattle, in the Coconut Plantations. SEPA.Vol. 10.No. 1. Sept 2013: 118-131.

[12] Suroyo., Suntoro and Suryono. 2013. Intercropping and Livestock Integration System to Change Physical and Chemical Properties Land Litosol.Soil Science, Journal of Soil Science and Agroclimatology 10 (1) 2013. P:71-80.

[13] Wahyuni, R. 2015. Mastery Structure Land Resources and Contribution of Beef Cattle on Farmer Household Income.Widyariset, Vol 18 No. 1, April 2015.p:79-90.

[14] Walia, S.S and N. Kaur. 2013. Integrated Farming System-An Ecofriendly Approach for Sustainable Agricultural Environment-A Review. Greener Journal of Agronomy Forestry and Horticulture. Vol. 1 (1). Sept 2013, p: 001-011. 